\title{
一様勾配斜面上の浅水波の砕波に及ぼす逆流の影響の表示法 \\ AN EXPRESSION FOR INFLUENCES OF OPPOSING CURRENT ON WAVE BREAKING OF SHOALING WAVE ON UNIFORM SLOPE
}

\author{
堺茂 樹*.平山健一**・佐伯 浩***
}

By Shigeki SAKAI, Ken-ichi HIRAYAMA and Hiroshi SAEKI

\begin{abstract}
Opposing currents affect the breaking processes of shoaling waves on uniform slopes. The wave breaking conditions depend on the normalized discharge per unit width of the opposing current as well as on the deep water wave steepness and uniform slope. Experiments were conducted to examine these effects on the breaker depth (or height) in the presence of the opposing current, as compare to the breaker depth (or height) in the absence of the current. A new empirical parameter was proposed to express the ratio of the breaker depth (or height) with and without the opposing current. The proposed new parameter accounts for the combined effects of the opposing current, deepwater wave steepness and uniform slope. The measured ratios of the breaker depth (or height) were shown to be expressed as a function of the proposed parameter

Keywords : breaker depth, breaker height, opposing current
\end{abstract}

\section{1. まえがき}

砕波現象は海岸工学上きわめて重要な問題の 1 つであ り，また本研究で扱う砕波特性に及ぼす逆流の影響は河 口付近あるいは海浜流の発生する海域での砕波を解明す るうえで考慮されなければならない要素の 1 つである.

砕波現象を流れの場で扱った最初のものは $\mathrm{Yu}^{1)}$ の研 究であり，深海波を対象とした流れによる砕波に関する 実験を行い, 砕波限界を検討している. 近年では, 岩垣・ 浅野・山中・永井 ${ }^{2)}$ が一様水深上の浅海波の逆流による 砕波の実験を行い, 砕波限界式として Miche の式が妥 当な近似を与えることを報告している.

著者ら ${ }^{3)}$ は斜面上での砕波に及ぼす逆流の影響に関す る実験から，砕波特性に及ぼす逆流の影響を表わすパラ メーターとして無次元単位幅流量（後述）がきわめて有 効であり, 砕波特性は水底勾配, 沖波波形勾配そして無 次元単位幅流量に依存していることを示し，逆流上の砕 波指標を提案した。この砕波指標では $1 / 50,1 / 30,1 / 15$ の 3 種類の水底勾配上で $0.006 \sim 0.08$ の範囲の数種類の

\footnotetext{
* 正会員 工博 岩手大学助手 工学部土木工学科 （元020 盛岡市上田 4-3-5）

** 正会員 Ph. D. 岩手大学教授 工学部土木工学科 (同上)

*** 正会員 工博 北海道大学教授 工学部土木工学科 ( 个060 札幌市北区北 13 西 8)
}

沖波波形勾配に対する砕波水深および砕波波高と無次元 単位幅流量との関係が示されている。しかし，これらの 関係が任意の水底勾配，沖波波形勾配で与えられている 方が実用的である.そのためには逆流の影響が定式化さ れ, さらにそれが水底勾配, 沖波波形勾配, 無次元単位 幅流量の影響を含む単一のパラメーターで表わされてい ることが望ましい.

本研究では逆流の影響を検討するため, 逆流が存在す る場合の砕波水深および砕波波高と存在しない場合の砕 波水深および砕波波高亡の比に着目する. 著者らが行っ た多くの実験の結果を再整理し, 水底勾配, 沖波波形勾 配, 無次元単位幅流量のすべての影響を含み, 前述の比 を一義的に決定し得るパラメーターを誘導する.さらに, このパラメーターにより砕波水深, 砕波波高に及ぼす逆 流の影響の定式化を行う。

\section{2. 実験装置および実験方法}

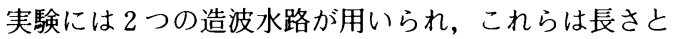
深さが若干異なっているが, 逆流の発生方法や造波装置 等は全く同一であり，その概略を図一1に示す．水路内 部は木製の隔壁により $36 \mathrm{~cm}$ 幅としてあり，これは単 位幅流量を広い範囲で変化させるために行われた。水路 内部の底面は $2 \mathrm{~m}$ の水平床と斜面部とから成り, 斜面 部の勾配 $S$ は1/50,1/30,1/15の 3 種類とした.これ 


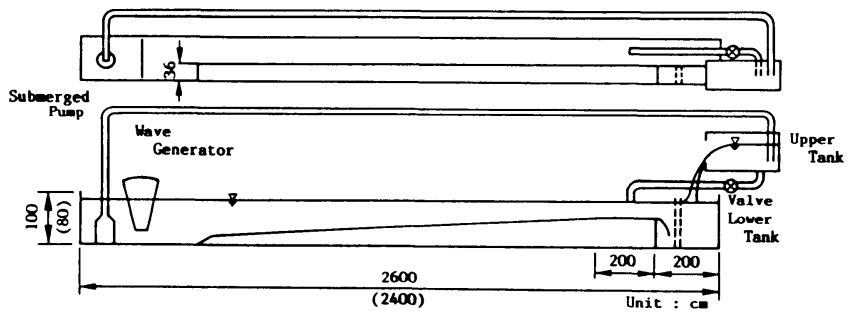

\begin{tabular}{|c|c|c|c|}
\hline \multicolumn{4}{|c|}{ 表一1 } \\
\hline 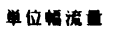 & $a$ & $0.0 \sim 790.0$ & $(\mathrm{~cm} 3 / \mathrm{s} / \mathrm{cm})$ \\
\hline 周彩 & $T$ & $0.83 \sim 2.40$ & (s.) \\
\hline 沖波波莴 & Ho & $1.1 \sim 24.0$ & (c口) \\
\hline
\end{tabular}

図一1 実験装置

ら底面は鋼製フレームにベニヤ板を張った物を用いて造 られている.

逆流を発生させるには，まず造波板の背後に設置した 水中ポンプにより水路岸側端の上方にある上部タンクに 送水する．上部タンクの四角せきを越流した水は水路内 の下部タンクへ落下するが，この際の水面の擾乱を静め るため下部タンクの内部に 2 枚のスクリーンが設置され ている．下部タンクから越流した水は $2 \mathrm{~m} の$ 水平床を 通過した後斜面上を逆流として流れる，流量を変化させ るには上部タンクの底部に設けたパイプを通して隔壁の 外側に送水し，流量の調整はパイプに付けたバルブの開 閉により行った。 また，水路内の水位は逆流を発生させ たときに $2 \mathrm{~m}$ の水平床上で跳水が生じたりあるいは水 面が著しく乱れることのないように各流量ごとに定め た。

水路幅が $36 \mathrm{~cm}$ 之比較的狭いため逆流流速の横断分 布には水路側壁の影響が現われる。また，水深が浅い所 での鈶直分布は底面の影響を受けるが，水深が深い所で は底面の近傍を除いてほぼ一様な分布となっている。

波形の測定には抵抗線式波高計と容量線式波高計が用 いられ，測定間隔は $S=1 / 50$ では $25 \mathrm{~cm}, S=1 / 30$, $1 / 15$ では $15 \mathrm{~cm}$ とした. また, 反射波の影響を除くため, 造波開始から 6 波目から 10 波目までの 5 波を測定した. 測定された波高の中で最大のものを砕波波高とし，その 測定位置を砕波点と定義する.

なお，本研究で用いたデー夕の実験条件を表一1に， また3.（2）で述べる方法により計算される沖波波形勾 配 $H_{0} / L_{0}$ と無次元単位幅流量 $q^{*}\left(q^{*}=q / g^{2} T^{3}, q\right.$ : 単 位幅流量, $T$ : 周期, $g$ : 重力加速度) の範囲を図一2 に示した.

\section{3. データの整理方法}

\section{（1）水深の定義}

逆流を発生させたときの平均水位の例を示したのが図 一3である。これは単位幅流量が $452 \mathrm{~cm}^{3} / \mathrm{s} / \mathrm{cm}$ の場合 であり, 平均水位は沖側の比較的深い所ではほぼ一定で あるが，水深が浅くなり逆流の平均流速が大きくなるに つれ, 平均水位は低下し, 流下方向に対して逆勾配となっ
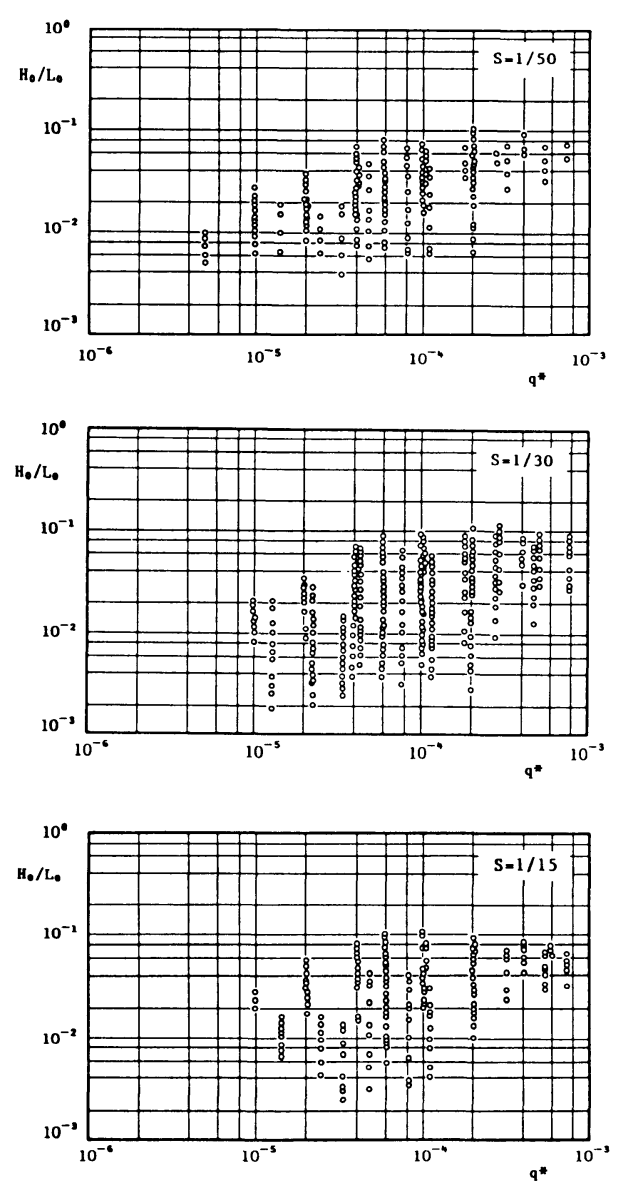

図一2 解析に用いたデータの $H_{0} / L_{0}$ と $q^{*}$ の範曲

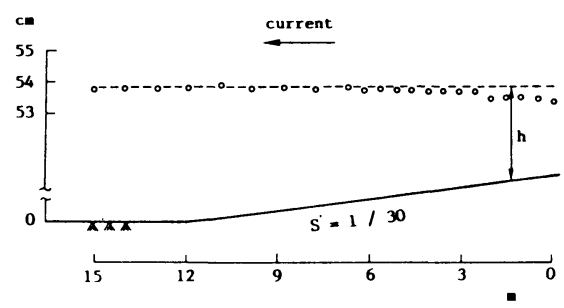

図一3 逆流による平均水位の変化と水深の定義

ている．この現象はすべての流量でみられたが，当然流 量が大きいほど顥著となる. 波が存在すると wave set- 
up, set-downによりさらに平均水位は変化する.

砕波現象は局所的な平均水深と密接な関係があり，砕 波点での波高, 波長, 水深間の関係あるいは逆流が存在 する場合には波速と逆流の平均流速との関係などの議論 には砕波水深として局所的平均水深を用いるべきであ る. しかし，局所的平均水深として定義される砕波水深 から砕波位置を算定するには砕波点での平均水位の変化 量も必要となる，一方，静水位を基準として定義される 水深からは直接砕波位置を算定することができ，実用的 である。

図一3に示したように比較的水深が深い沖側では平均 水位はほぼ一定であり，ここでの平均流速を用いて計算 される速度水頭は最大でも $1 \mathrm{~mm}$ 以下であった. そこで， 沖側での平均水位（図中破線）を静水位とみなし，これ から底面までの深さを水深と定義する。

\section{（2）沖波波高の計算}
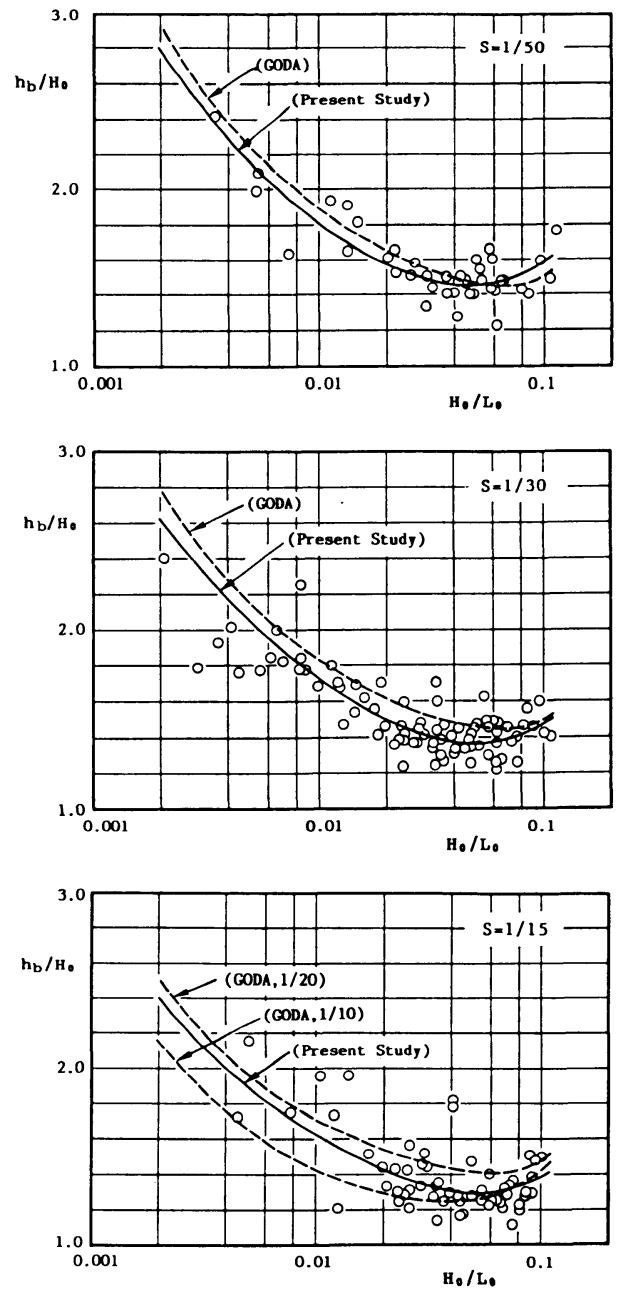

図一4 逆流が存在しない場合の砕波水深
著者ら ${ }^{4)}$ は流れおよび波動による平均水位の変化を考 慮に入れたエネルギーフラックスは式（1）で計算され ること，および波動の線形解を代入しエネルギ一損失が ないとした場合のエネルギ一保存は式（2）で表わされ ることを示した.

$$
E_{f}=-\rho \overline{\int_{-h}^{5} \phi_{i} \cdot \phi_{x} d z}
$$

ここで, $E_{f}$ : エネルギーフラックス, $\rho:$ 流体の密度, $\zeta:$ 水位, $h:$ 水深, $\phi:$ 速度ポテンシャル (ただし, ベ ルヌーイの定数に関連する任意関数を含まない), 添字 $t, x$ はおのおの時間および水平方向の偏微分を表わし, また $\boldsymbol{z}$ は鈶直軸である。なお，右辺は時間に関する平 均值である.

$$
\left(c_{g}-U\right) \cdot\left(1-\frac{U}{c}\right) \cdot E=c_{g 0} \cdot E_{0}=\text { const. }
$$

ここで, $c_{g}$ : 流れに対する相対的群速度， $U$ : 流れの平
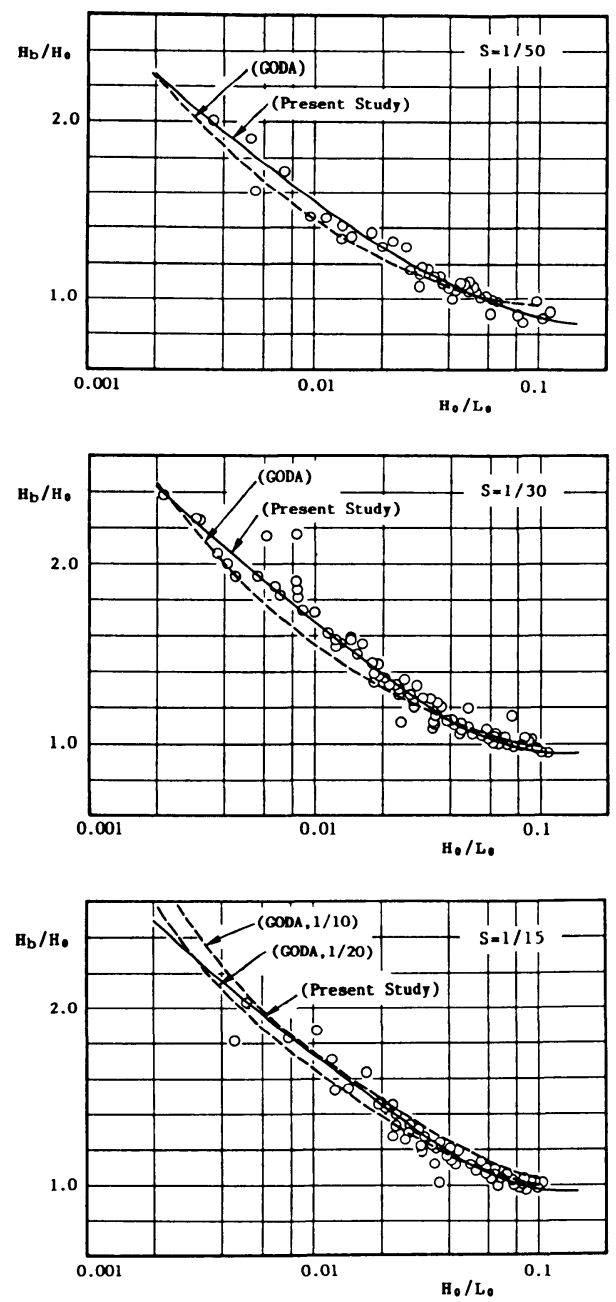

図一5 逆流が存在しない場合の砕波波高 
均流速, $c$ ：流れに対する相対的波速， $E$ : エネルギー 密度, 添字 0 は流れが存在しない深海での值を示す.

上式は流速の鉛直分布が一様である場合に対するもの であり,また2. で述べたように本研究での水深の深い 所での逆流流速も鉛直方向にほぼ一様であったことか ら, 深い水深を有する斜面上の $2 \sim 3$ 点での水深と波高 を用い式（2）から沖波波高を計算した。 なお，逆流が 存在しない深海での波長 $L_{0}$ は $L_{0}=g T^{2} / 2 \pi$ である.

\section{4. 新しいパラメーターによる逆流の影響の総 合的評価}

\section{（1）逆流が存在しない場合の砕波水深，砕波波高}

本研究では砕波特性に及ぼす逆流の影響を検討するた め, 逆流が存在する場合の砕波水深および确波波高之逆 流が存在しない場合の砕波水深および砕波波高との比に 着目する. まず，基準となる逆流が存在しない場合の砕 波水梁, 砕波波高を決定する必要がある. 図一4, 図-5 は本研究での逆流が存在しない場合の実験で得られた $h_{b} / H_{0}\left(h_{b}\right.$ : 砕波水深, $H_{0}$ : 沖波波高) と $H_{0} / L_{0}$ (沖波 波形勾配）の関係および $H_{b} / H_{0}\left(H_{b}\right.$ : 砕波波高）亡 $H_{0} / L_{0}$ の関係を水底勾配別に示したものである. 砕波水 深に関する結果には多少ばらつきがあるものの, 全体的 には図中の実線で示される平均曲線が得られ, 以下の検 討では逆流が存在しない場合の砕波水深, 砝波波高とし てこれらの平均曲線の值を用いる. なお, 従来の研究結 果と比較するため図中には合田により提案された砕波指 標が破線で示されている. 実験結果と砕波指標を比較す ると多少異なる部分もあるが，この差は合田が䂶波指標 を検討する際に用いたいくつかの実験結果と砕波指標之 の差と同程度のものであり, むしろ本研究での結果は合 田の砕波指標よよく一致しているといえる。

\section{（2）新しいパラメーターの誘導}

著者ら ${ }^{3 / .4)}$ は波浪変形に及ぼす逆流の影響を表わすパ ラメーターとして無次元単位幅流量 $q^{*}$ がきわめて有効 であることをすでに報告している，そこで, 逆流が存在 する場合の砕波水深 $\left(h_{b}\right) c$ 之存在しない場合の砕波水深 $\left(h_{b}\right)_{n c}$ との比 $R_{h}=\left(h_{b}\right)_{c} /\left(h_{b}\right)_{n c}$ に対する $q^{*}$ の影響を検討 する. 図一6は $R_{h}$ と $q^{*}$ の関係を沖波波形勾配別に示 したものであり，たとえば沖波波形勾配が 0.006 と分類 されているものには 0.006 の $5 \%$ の範囲 $(0.0057$ $0.0063)$ にあるものも含まれている. $R_{h}$ は $q^{*}$ の増加 に伴い直線的に増加している. また, その増加率は $H_{0} /$ $L_{0}$ によって大きく異なり， $H_{0} / L_{0}$ が小さいほど増加率 は大きく, 逆流の影響が強く現われている. 図中の実線 はおのおのの $H_{0} / L_{0}$ に対して最少二乗法により計算さ れた回帰直線である. 図一6 は水底勾配 $S=1 / 30$ の場 合であり, $S=1 / 15,1 / 50$ でも定性的には全く同一の傾

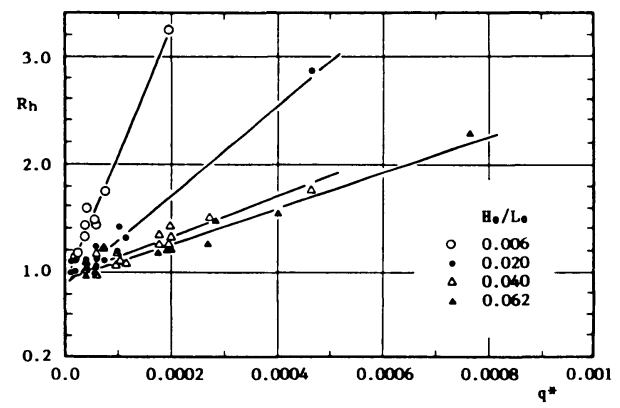

図一6 砕波水深に関する比 $\boldsymbol{R}_{\boldsymbol{h}}$ と $\boldsymbol{q}^{*}$ の関係 $(S=1 / 30)$

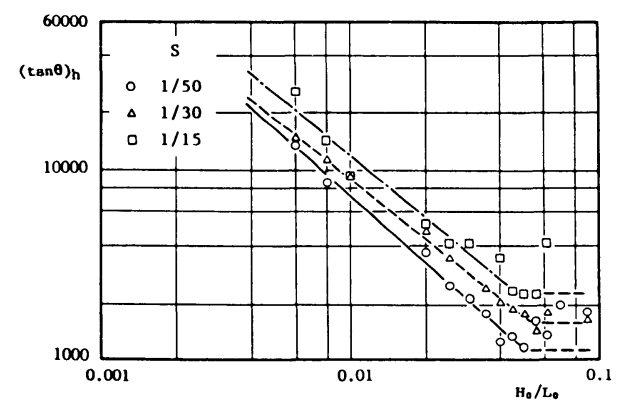

図一 $(\tan \theta)_{h}$ と $H_{0} / L_{0}$ の関係

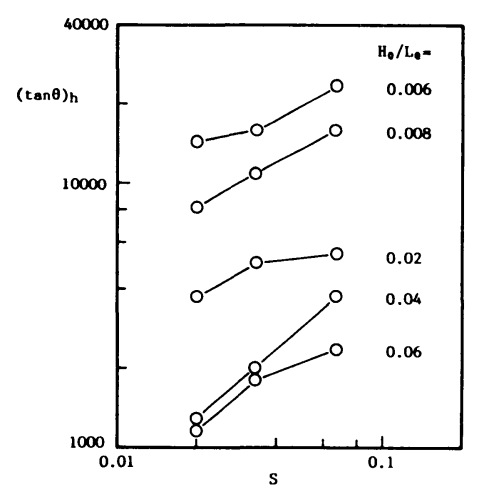

図一8 $(\tan \theta)_{h}$ と水底勾配 $S$ の関係

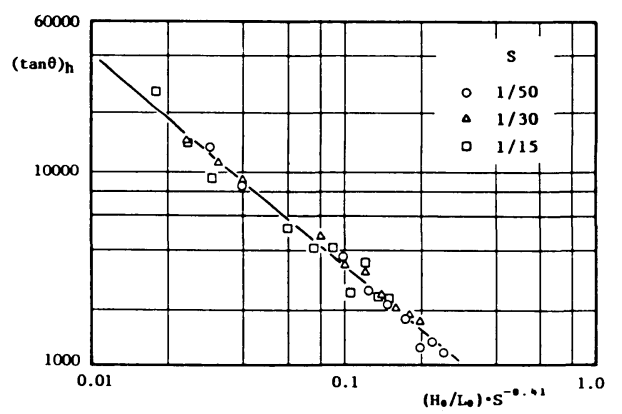

図一9 $H_{0} / L_{0}$ と $S$ を組み合わせた量と $(\tan \theta)_{h}$ の関係

向を示すが, おのおのの沖波波形勾配での増加率は水底 勾配によって異なっている. つまり， $q^{*}$ の増加に伴う 
$R_{h}$ の増加率は沖波波形勾配と水底勾配に依存している ことがわかる.

増加率の特性を調べるため, 図一6中の回帰直線の傾 き $(\tan \theta)_{h}$ と $H_{0} / L_{0}$ の関係を両対数紙上で示したのが 図一7である. 水底勾配別に示されているが，いずれの 水底勾配においても $H_{0} / L_{0} \leqq 0.05$ の範囲では $(\tan \theta)_{h}$ は $H_{0} / L_{0}$ の増加に伴い直線的に減少している. $H_{0} / L_{0}>$ 0.05 では若干不規則に変化しているが,ここではほぼ 一定値亡なるものとする. 以上のことより，( $(\tan \theta)_{h}$ は 式（3）で表わすことができる.

$$
(\tan \theta)_{h} \propto\left\{\begin{array}{ll}
\left(H_{0} / L_{0}\right)^{a} & H_{0} / L_{0} \leqq 0.05 \\
0.05^{a} & H_{0} / L_{0}>0.05
\end{array} .\right.
$$

また, 図中の実線は $H_{0} / L_{0} \leqq 0.05$ 範囲での回帰直線 であり，その傾きは水底勾配にかかわらずほぼ同一であ るが, $(\tan \theta)_{h}$ の值は水底勾配が急であるほど大きい. $(\tan \theta)_{h}$ 亡水底勾配との関係を $H_{0} / L_{0}$ 別にしたのが図一 8 である. 若干のばらつきはあるが, 全体的には水底勾 配が大きいほよ゙傾きも大きくなっており, 以下の関係が みられる.

$(\tan \theta)_{h} \propto S^{b}$

結局, 式 (3), (4) より,

$$
(\tan \theta)_{h} \propto\left\{\begin{array}{cl}
\left(H_{0} / L_{0}\right)^{a} \cdot S^{b} & \\
=\left(\left(H_{0} / L_{0}\right) \cdot S^{c}\right)^{a} & H_{0} / L_{0} \leqq 0.05 \cdots(5) \\
\left(0.05 \cdot S^{c}\right)^{a} & H_{0} / L_{0}>0.05
\end{array}\right.
$$

が得られる. そこで, 両対数紙上の縦軸に $(\tan \theta)_{h}$, 横 軸に $\left(H_{0} / L_{0}\right) S^{c}$ をとり, 最小二乗法で求まる回帰直線の 相関係数が最も高くなる $c$ を求める. その結果, $c=-$ 0.41 で相関係数は 0.98 となるが, $-0.76<c<-0.11$ の範囲でも 0.97 以上の相関係数が得られる. 図一9は $c=-0.41$ とした場合であり, $(\tan \theta)_{h}$ に対する水底勾 配と沖波波形勾配の影響がよく表現されている. 図中の 回帰直線の傾きから

$$
(\tan \theta)_{h} \propto\left\{\begin{array}{cc}
\left(\left(H_{0} / L_{0}\right) \cdot S^{-0.41}\right)^{-1.01} & \\
=\left(H_{0} / L_{0}\right)^{-1.01} \cdot S^{0.41} & H_{0} / L_{0} \leqq 0.05 \\
0.05^{-1.01} \cdot S^{0.41} & H_{0} / L_{0}>0.05
\end{array}\right.
$$

\section{となる。}

以上は $q^{*}$ の増加に伴う $R_{h}$ の増加率と $H_{0} / L_{0}, S$ の 関係についてであるが, 砕波波高に関する比 $R_{H}\left(R_{H}=\right.$ $\left.\left(H_{b}\right)_{c} /\left(H_{b}\right)_{n c}\right),\left(H_{b}\right)_{c}$ : 逆流が存在する場合の砕波波高, $\left(H_{b}\right)_{n c}$ : 逆流が存在しない場合の砕波波高) と $q^{*}$ の関 係における増加率 $(\tan \theta)_{H}$ について同様な検討を行う. 図一10は水底勾配 $S=1 / 30$ での $R_{H}$ と $q^{*}$ との関係を示 したものである. $R_{H}$ と $q^{*}$ の関係に対する $H_{0} / L_{0}$ の影 響は図一6に示した $R_{h}$ と $q^{*}$ の関係に対するものほど

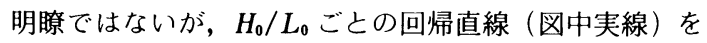
比較すると $q^{*}$ に伴う $R_{H}$ の増加率も $H_{0} / L_{0}$ に依存して
いることがわかる. $R_{H}$ の増加率は $R_{h}$ の増加率に比べ 小さいため, 回帰直線の傾きは $q^{*}$ の大きい所での $R_{H}$ の変動に大きく影響される. そのため傾き $(\tan \theta)_{\boldsymbol{H}}$ と $H_{0} / L_{0}$ あるいは $S$ との関係は図一7あるいは図一8で示 した $(\tan \theta)_{h}$ に関するものに比べばらつきが大きい. そこで, 傾きとして妥当な值と判断された結果のみを用 いて直接 $(\tan \theta)_{H}$ と $\left(H_{0} / L_{0}\right) S^{c^{\prime}}$ との関係を検討すると, $c^{\prime}=-0.37$ で相関係数は 0.98 となり, またー $0.65 \leqq$ $c^{\prime} \leqq-0.14$ の範囲で相関係数は 0.97 以上となる. 図一 11 は $c^{\prime}=-0.37$ とした場合であり, 図一9 と同様水底 勾配と沖波波形勾配の影響をよく表わしている. 図中の 回帰直線の傾きから， $(\tan \theta)_{H}$ は以下の式で表わすこと ができる.

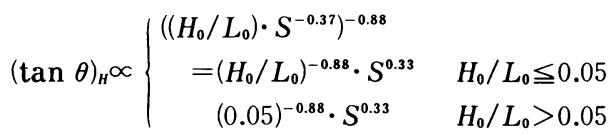

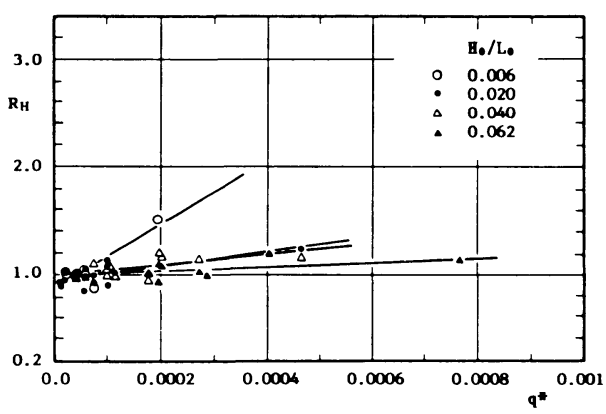

図一10 砕波波高に関する比 $\boldsymbol{R}_{\boldsymbol{H}}$ と $\boldsymbol{q}^{*}$ の関係 $(S=1 / 30)$

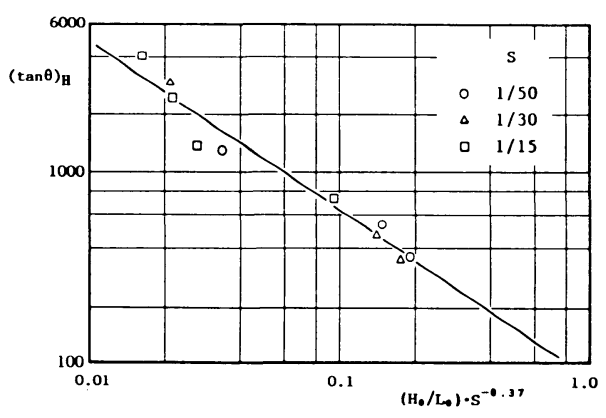

図一11 $H_{0} / L_{0}$ と $S$ を組み合わせた量と $(\tan \theta)_{H}$ の関係

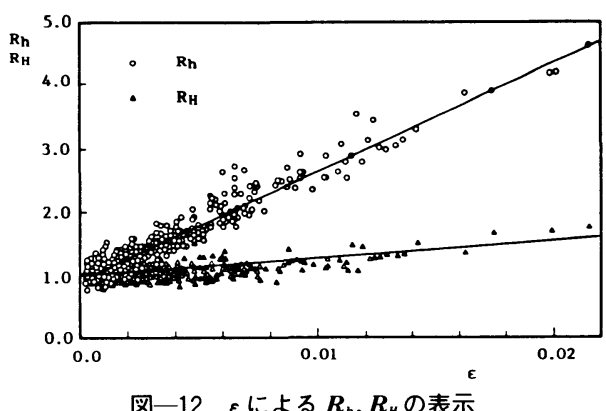

図一12 $\varepsilon$ による $\boldsymbol{R}_{h}, \boldsymbol{R}_{H}$ の表示 
( 7 )

以上のように, $R_{h}, R_{H}$ と $q^{*}$ の関係における回帰直 線の傾き $(\tan \theta)_{h},(\tan \theta)_{H}$ と $H_{0} / L_{0}$ および $S$ との関係 が明らかとなった。そこで，図一6および図一10に示さ れる $R_{h}, R_{H}$ と $q^{*}$ の直線的関係を $R_{h}$ と $q^{*} \cdot(\tan \theta)_{h}$ あ るいは $R_{H}$ と $q^{*} \cdot(\tan \theta)_{H}$ の関係に書き替えると, $H_{0} /$ $L_{0}, S$ にかかわらず 1 本の直線で表わされることにな る. 式 ( 6$),(7)$ に示すように, $(\tan \theta)_{h}$ と $(\tan \theta)_{H}$ と では $H_{0} / L_{0}, q^{*}$ の乗数が若干異なる. しかし，碎波水深， 砕波波高とも同一のパラメーターで表わされることが望 ましい. 高い相関が得られる $c, c^{\prime}$ の範用が比較的広い ことから図一9, 図一11 の関係をあまり損なわず，さら に計算の簡便さを考慮し, 以下の量を定義する.

$$
\varepsilon= \begin{cases}\frac{q^{*}}{H_{0} / L_{0}} \sqrt[4]{S} & H_{0} / L_{0} \leqq 0.05 \\ \frac{q^{*}}{0.05} \sqrt[4]{S} & H_{0} / L_{0}>0.05\end{cases}
$$

$\varepsilon$ を用いて全実験結果を表わすと, 図一12 となり， $R_{h}, R_{H}$ と $\varepsilon$ の間にはきわめて明瞭な直線関係がみられ， 水底勾配，沖波波形勾配の影響を含めた逆流の影響がよ く表現されている. $R_{h}$ に関しては $\varepsilon<0.0004$ では $R_{h}$ $=1$ となり $\varepsilon \geqq 0.0004$ の範囲での回締直線から

$$
R_{h}= \begin{cases}0.93+170 \varepsilon & \varepsilon \geqq 0.0004 \\ 1.0 & \varepsilon<0.0004\end{cases}
$$

また $R_{H}$ は

$$
R_{H}= \begin{cases}0.96+30 \varepsilon & \varepsilon \geqq 0.0013 \\ 1.0 & \varepsilon<0.0013\end{cases}
$$

となり，逆流の影響が定式化される.

\section{5.むすび}

著者らの行った逆流が存在する斜面上での波浪の変形
に関する多くの実験の結果を再整理し，逆流が存在する 場合の砕波水深および研波波高と逆流が存在しない場合 の砕波水深および砕波波高との比を求め,これらと水底 勾配, 沖波波形勾配, 無次元単位幅流量との関係を検討 した. その結果, 式 (8) で定義されるパラメーター は逆流による砕波特性の変化に対する無次元単位幅流 量, 沖波波形勾配, 水底勾配の影響をよく表わすことが 明らかになった。また，図一2に示す範囲においては, このパラメーターを用いて砕波水深，研波波高に及ぼす 逆流の影響を定式化することができた（式（9)，(10)）.

最後に，本研究に際し有益なご助言を賜った首藤伸夫 教授（東北大学工学部）に深甚なる謝意を表します。ま た, 実験結果の整理および解析にあたり笹本 誠技官(岩 手大学工学部), 当時岩手大学大学院生 冷水康悦君亡学 生秋山喜弘君の多大な協力を得たことを記し，ここに感 謝の意を表します。

\section{参 考 文 献}

1) $\mathrm{Yu}, \mathrm{Y} . \mathrm{Y}$. : Breaking of waves by opposing current, Trans. A.G.U., Vol. 33, No. 1, pp. 39 41, 1952.

2）岩垣雄一・浅野敏之・山中庸彦・永井文博：流れによる 砕波に関する基礎的研究, 第 27 回海岸工学講演会論文集, pp. 30 34, 1980.

3）堺 茂樹 · 大塚夏彦・佐伯 浩 - 尾崎 晃: 斜面上での 砕波に及ぼす流れの影響に関する基礎的研究, 第 28 回海 岸工学講演会論文集, pp. 138 142, 1981.

4) Sakai, S. and Saeki, H. : Effects of opposing current on wave transformation, Proceedings of 19th International Conference on Coastal Engineering, Vol.2, pp.1132 $1148,1984$.

5）合田良実：砕波指標の整理について，土木学会論文報告 集, 第 180 号, pp. 39 49, 1970.

(1987.5.20 - 受付) 